\title{
Connecting the Dots for Social Value: A Review on Social Networks and Social Entrepreneurship
}

\author{
FREDERIC DUFAYS \& BENJAMIN HUYBRECHTS
}

Centre for Social Economy, HEC Management School, University of Liege, Liege, Belgium

\begin{abstract}
The emergence of social entrepreneurship has been explained at the macro-level (socioeconomic drivers), at the meso-level (concepts such as opportunity), and at the micro-level (motivations and intentions of social entrepreneurs). In this conceptual article, it is argued that the sociology of social networks may contribute to explain how and why social entrepreneurship arises by bridging micro- and macro-levels of analysis. Four different usages of the social network concept in the social entrepreneurship literature are identified: embeddedness of social entrepreneurship, collective social entrepreneurship, networking as a critical skill or activity of social entrepreneurship, and finally networking and the creation of social capital as a goal of social entrepreneurship. Theoretical frameworks explaining the emergence of conventional entrepreneurship with a social network lens are identified. These are evaluated with regard to social entrepreneurship and translated into a set of research proposals to be explored in order to strengthen our understanding of social entrepreneurship emergence.
\end{abstract}

KEY WORDS: Social networks, social entrepreneurship, embeddedness, collective entrepreneurship

\section{Introduction}

As an emerging field of research, social entrepreneurship has given rise to numerous definitions (for reviews, see Short, Moss, and Lumpkin 2009; Dacin, Dacin, and Matear 2010; Bacq and Janssen 2011). Besides attempts to describe what social entrepreneurship is, many studies are devoted to identify what it is not. In particular, its distinguishing features as compared to commercial entrepreneurship are central to several studies (Austin, Stevenson, and Wei-Skillern 2006; Shaw and Carter 2007; Trivedi and Stokols 2011; Lumpkin et al. 2013). However, only few studies examine the reasons why, and the processes through which, social entrepreneurship emerges. This gap is partially due to the difficulty to study an object that is weakly circumscribed (Davidsson and Wiklund 2001) and highly contested (Dey andSteyaert 2010).

At a macro-level, four drivers for social entrepreneurship are identified by Huybrechts and Nicholls (2012). First, social and environmental actions are called for by an increasing number of global crises. Second, citizens are more and more aware of social and environmental needs as new information technologies develop. Third, in the context of the new public management, the creation of internal 'quasi-markets' for public and quasi-public goods has redefined the role of the state towards supporting private actions for the public good. In this regard, Dey (2013) argues that social entrepreneurship has been introduced as a tool for the neo-capitalist view (governmentality) of disengaging the state from the social welfare arena. Finally, in a context of economic crisis and 
decrease in public funding, a growing number of organizations pursuing a social mission have explored ways to increase commercial revenues or engage in partnerships with the public and private sectors.

Economists working on non-profit organizations advance the market and state-failure arguments to explain why there is a demand for non-profit and other 'third-sector' organizations (for reviews, see Anheier 2005; Steinberg 2006). Santos (2012) refines this argument with respect to social entrepreneurship and argues that the latter consists in creating value - as opposed to capturing value - by pursuing sustainable solutions to neglected problems with positive externalities in situations of simultaneous market and government failure.

At a meso-level, following a concept that has become paradigmatic in the entrepreneurship literature (Chabaud and Messeghem 2012), opportunities have been explored in a social entrepreneurship context. These are considered from three perspectives: the allocative view, the discovery view, and the creation view (Lehner and Kaniskas 2012). Regarding the latter, social entrepreneurship opportunities are said to be geographically situated (Cajaiba-Santana 2010), created by prospection (Corner and Ho 2010) and by interaction with the environment, with the skills and resources at hand (Korsgaard 2011), in response to an identified social need.

Finally, at a micro-level, motivations and intentions of social entrepreneurs to create a social enterprise are argued to be positively related to empathy, moral judgement, self-efficacy beliefs, and social support (Mair and Noboa 2006). Social entrepreneurs are also found to be motivated by a blend of self-actualization, achievement orientation, the desire to help society, the closeness to a social problem, and an absence of financial focus (Germak and Robinson 2013). In the non-profit literature, supply-side theories also focus on the profile and the individual preferences of the entrepreneur, explaining the differences between entrepreneurs by the variations in their objective function (Ben-Ner and Van Hoomissen 1991; Badelt 1997; Bilodeau and Slivinski 1998). Similarly, traits and values of the social entrepreneur have also been looked at as a factor explaining the emergence of social entrepreneurship (Hemingway 2005; Koe Hwee Nga and Shamuganathan 2010).

In this article, it is contended that existing theories are insufficient to capture the rationale for the emergence of social entrepreneurship, particularly the dynamics of emergence at the inter-personal level. Among the theories available to elaborate upon, our contribution here is to show how the sociology of social networks is of particular interest in explaining the emergence of social entrepreneurship across different levels of analysis. Indeed, while there have already been several calls for research on social networks in the context of social entrepreneurship (Haugh 2005; Mair and Marti 2006; Certo and Miller 2008; Short, Moss, and Lumpkin 2009; Gedajlovic et al. 2013; Busch 2014), these calls have only been answered very partially. Hence, based on the use of social network theory in the conventional entrepreneurship literature, this article examines how this theoretical body could be exploited in order to explain the emergence of social entrepreneurship. Four research proposals that may contribute to a stronger and more analytical (as opposed to descriptive) understanding of social entrepreneurship emergence are proposed. These research proposals may also contribute, once implemented in social entrepreneurship, to building theory on social networks in complex and 'hybrid' entrepreneurial settings (see, for instance, Dorado and Ventresca 2013; Edwards and Baker 2013; Doherty, Haugh, and Lyon 2014). 
In the next section, the sociology of social networks is set out and justified as particularly relevant to examine and explain social entrepreneurship. Then, in order to clarify the research gap, the extant literature on social entrepreneurship dealing with social networks is reviewed. Four broad categories of usage of the notion of social network are distinguished: embeddedness of social entrepreneurship, collective social entrepreneurship, networking as a critical skill of social entrepreneurs or a fundamental activity of social entrepreneurship, and creation of social ties as an outcome or an objective of social entrepreneurship. Next, within the traditional (commercial) entrepreneurship literature, theoretical frameworks that see social networks as drivers of entrepreneurship are identified. More particularly, distribution issues, diffusion of ideas, structural holes, and network crystallization are identified as promising avenues to explain social entrepreneurship emergence as a collective process. These avenues are finally translated into concrete proposals for future research in social entrepreneurship. The contributions of this article for both research and practice are outlined in the conclusion

\section{The Sociology of Social Networks}

It is generally acknowledged that the social network approach takes its roots in Simmel's work (Mercklé 2004). Indeed, Simmel argues that sociology must study interactions and social relationships between individuals, rather than individuals and their attributes. Throughout his diverse work, he puts the emphasis on what he calls the 'social forms' that emerge from relationships between individuals. In turn, these social forms acquire some autonomy and shape the interactions between individuals (Simmel 1909; Frisby 2002). This articulation between the microand the macro-levels constitutes one pillar of the social network approach.

Following Simmel, the sociology of social networks studies relationships between actors, be it individuals or organizations. Formalized concepts and measures have been developed to help characterize the position of a particular actor in the network, the relationships between different actors, or even the whole network (Wasserman and Faust 1994; Scott 2000; Mercklé 2004), and look how they impact individual behaviour (e.g. Granovetter 1973), as well as social phenomena (e.g. Kadushin 1995). Conversely, one can also look how these evolve when actors are confronted with some events (e.g. Bidart, Degenne, and Grossetti 2011) or in the course of a socioeconomic process such as entrepreneurship (Slotte-Kock and Coviello 2010).

Closely related to the notion of social networks are the concepts of social capital and embeddedness. The former is defined in several ways (among the leading authors: Bourdieu 1980; Coleman 1988; Putnam 1995; Portes 1998; Lin 2001), but all insist on the same intuition: relationships matter and constitute a form of capital that may be transformed into other forms of capital (human capital, financial capital, etc.). The embeddedness argument, as stated by Granovetter (1985), indicates that economic phenomena do not occur in a vacuum. More specifically, they are embedded in a network of social relationships.

Why are social networks useful to understand social entrepreneurship? In general terms, Granovetter (2005) argues that social networks influence the economy in three broad ways. First, social networks affect the flow and the quality of information. Second, they constitute an important source of rewards and punishments. Third, social networks help trust to emerge, which in turn is 
likely to affect the transactional behaviour of actors. As a consequence of these three main effects, social networks are likely to influence the access to resources, the organizational effectiveness, and the building of legitimacy, each of which appears as particularly challenging in a social entrepreneurship context. To further explore the contributions of the social network lens to the understanding of social entrepreneurship, the social entrepreneurship literature that deals with social networks is reviewed in the following section.

\section{Social Entrepreneurship and Social Networks - A Literature Review}

With some notable exceptions (Haugh 2007; Dal Forno and Merlone 2009), the social network approach has not been applied in a social entrepreneurship context. Nevertheless, some studies deal with social networks or related concepts. The Business Source Premier (EBSCOhost) database, limited to peer-reviewed academic journals, includes 541 articles dealing with social entrepreneurship (search terms in title, abstract, and keywords: 'social entrepreneur*'). Among those, only 18 include the terms 'social network*', out of which 5 papers were dismissed because they did not deal with social entrepreneurship (1), were an editorial note or an opinion (2), used the term 'social network' to mean 'social media' (1) or had only the abstract in English (1). The 13 remaining articles explicitly used social networks and related concepts as a central focus. Four different uses of social networks were identified: the embeddedness concept, collective entrepreneurship, networking as a critical skill for success or fundamental activity of social entrepreneurship, and the creation of social ties and social capital as an objective of social entrepreneurship. A snowball method was also used starting from these articles as well as from research agendas for social entrepreneurship that mention social networks to check whether other usages of the concept could be found in the literature; yet this did not seem to be the case.

\section{An Embedded Entrepreneurship}

As mentioned earlier, the concept of embeddedness is closely related to the notion of social networks in economic sociology (Dacin, Beal, and Ventresca 1999; Beckert 2009). Explaining differences in economic regimes, Polanyi ([1944] 2001) argues that the economy is embedded in economic and non-economic institutions. Bringing the concept into the field of economic sociology, Granovetter (1985) restrains it by considering economic activities as being embedded in systems of social interactions, i.e. in social networks. Both Polanyi's broad view and Granovetter's narrower understanding of embeddedness are used in the social entrepreneurship literature.

Authors such as Laville, Lemaitre, and Nyssens (2006) adopt the broader conception and use the notion of embeddedness to show that social entrepreneurship has to be conceived in the relationships it maintains with other groups, other sectors of activity. In a study on Work Integration Social Enterprises (WISEs), Gardin (2006) argues that social entrepreneurship is both embedded socially and politically, in addition to reticular embeddedness. Seelos et al. (2011) integrate the embeddedness concept into a broader institutional theory framework. They observe that social enterprises are embedded in their local community. Laville and Nyssens (2001) consider social enterprises to be embedded in the three poles of economy identified by Polanyi - the market economy, the non-market economy, and the non-monetary economy. According to them, social enterprises' sustainability is linked to their ability to hybridize these three poles around their project for the benefit of their community. 
Several scholars advocate that social entrepreneurship may not be understood in purely economic terms, but needs to be studied in relationship with its (local) social environment (Mair and Marti 2006; Khavul and Bruton 2013). Hence, the embeddedness of social entrepreneurship at its different stages constitutes a promising avenue for research. More precisely, Mair and Marti (2006) suggest different theoretical frameworks to articulate this idea of embeddedness: structuration theory, institutional entrepreneurship, social capital, and social movements. They stress that embeddedness may have positive as well as negative effects on social entrepreneurship, which should not be underestimated in future research. For example, structural and relational overembeddedness may reduce the diversity of ideas to which an individual is exposed, which may result in inertia. Therefore, overembeddedness may have a negative effect on the intention formation stage of social entrepreneurship.

Drawing on structural or network embeddedness according to Granovetter's understanding of the term, Shaw and Carter (2007) observe that social entrepreneurship differs from commercial entrepreneurship in the former's embeddedness in the local networks of the community. It is indeed at the community level that social entrepreneurs identify local social needs and try to develop solutions to fulfil these needs. Acknowledging that social entrepreneurship may address broader social needs and is not limited to a local scale, Smith and Stevens (2010) relate three profiles of social entrepreneurs to three types of structural embeddedness, as well as to the scaling strategies they are likely to use. According to them, the more locally a social entrepreneur is acting, the more important their structural embeddedness will be because the more their social ties will be at arm's length. Further, they suggest that, when confronted with scaling, more structurally embedded social entrepreneurs are more likely to adopt a deepening strategy in contrast to a broadening scaling strategy.

Looking at the evolution of non-profits and for-profits towards a social enterprise model - a process termed social intrapreneurship - in a comparative multiple-case study, Kistruck and Beamish (2010) observe that network embeddedness tends to have a positive role for for-profits and a negative role for non-profits. Indeed, in contrast to their expectations, non-profits experienced a loss of social capital when changing the transactional nature of the relationships with actors in their network to include a commercial dimension. This happened because the change was perceived as a sign of opportunism.

Summing up, embeddedness can be conceived as a key feature of social entrepreneurship, as it involves sociopolitical objectives, and has to be conceived in the relationships it involves with other actors. Further, social entrepreneurship may sometimes be deeply rooted in the local community network, in which opportunities, as well as partners and resources to exploit them, are found. The strong embeddedness of social entrepreneurship implies an important and complex interaction between the social entrepreneur and their environment, which infers at least two levels of analysis in the studies dealing with this concept - i.e. macro and micro. If embeddedness implies looking at all relationships around social entrepreneurship, a narrower perspective may concentrate on the stronger ties on which cooperation or coalitions of actors are formed to conduct social entrepreneurship. Let us now turn to the latter perspective.

\section{A Collective Entrepreneurship}


Building on a tradition of acknowledging a collective aspect to the emergence of social enterprises (Ben-Ner and Van Hoomissen 1991; Defourny and Delvetere 1999; Borzaga and Defourny 2001; Defourny 2001), a second theme lies in collective social entrepreneurship. By this term, it is meant that the 'social entrepreneur' often consists of a coalition of individuals or actors rather than just a single individual. Collective social entrepreneurship includes among others the setting up of cooperatives (Spear 2012; Huybrechts and Mertens 2014) and community entrepreneurship (Johannisson 1990).

Looking for distinguishing features of social entrepreneurship as compared to traditional for-profit entrepreneurship, Shaw and Carter (2007) state that social entrepreneurship is a collective, rather than an individual activity. This assertion comes from their observation that the structure of the social enterprise is most often collective (e.g. cooperative legal form, involvement of stakeholders in the organizational structure). Consequently, in the case of a single individual founder, their role is perceived as being driven by complexity because it entails coordinating a coalition of different actors. In the same vein, Thompson and Doherty (2006) observe that, even though in some enterprises there is a significant contribution of a pivotal social entrepreneur, the leadership of social enterprises is often taken up collectively.

As a result of an inductive multiple-case study, Corner and Ho (2010) note the extent to which multiple actors are involved in opportunity development in social entrepreneurship. They observe that actors form coalitions because the necessary knowledge for innovation to create social value is distributed among multiple actors. Similarly, Schieb-Bienfait, Charles-Pauvers, and Urbain (2009) report that the majority of projects in a sample of 147 innovating projects in the French social and solidarity economy context have a collective dimension in their genesis. This collective aspect is even reinforced over time as the project evolves. They argue that the projects' collective dimension is either reflected in a crystallization of a subpart of the social network of the social entrepreneurs bearing the project, or in the formation of a chain of actors adding social value one after the other.

This partnering of actors in a later phase of social entrepreneurship is also put forward by Montgomery, Dacin, and Dacin (2012), who argue that social entrepreneurship emerges from the pooling or the trading of resources by multiple actors. This collaborative and collective social entrepreneurship aims to 'build awareness, gain resources, and ultimately make change' (376). Several authors examining social enterprise governance also insist on this collective or network form of organization in social entrepreneurship, which results from the mobilization of a variety of actors towards a common social goal or mission (Campi, Defourny, and Grégoire 2006; Hervieux and Turcotte 2010; Calton et al. 2013; Huybrechts, Mertens, and Rijpens 2014). When these actors originate from different backgrounds and rely on different institutional logics, collective entrepreneurship may be a strong driver for the emergence of social enterprises as hybrid organizations (Battilana and Dorado 2010; Huybrechts 2012; Doherty, Haugh, and Lyon 2014).

Consequently, it is reasonable to assume that a large part of social entrepreneurship initiatives involves a collective dynamics around a coalition of actors. Applying the social network lens to this theme involves governance and intraorganizational analyses, this is, at the meso-level. However, for these partnerships and for these forms of collective entrepreneurship to be successful, it is often necessary that one or several individuals manage the social network by adopting a coordinating role 
(Schieb-Bienfait, Charles-Pauvers, and Urbain 2009; Arenius and Laitinen 2011), which is a micro-level skill or activity examined in the next subsection.

\section{A Critical Skill of Social Entrepreneurs and a Fundamental Activity of Social Entrepreneurship}

The most common usage of the notion of social network in the social entrepreneurship literature is to consider networking as a critical skill for success or as a core activity of social entrepreneurship. Four different approaches are identified: distinguishing social entrepreneurship from commercial entrepreneurship in terms of social network, linking social network and resources, classifying the different types of social networks mobilized, and considering social networks as a fundamental dimension or activity of social entrepreneurship.

In a literature review contrasting the different schools of thought in the social entrepreneurship field, Hoogendoorn, Pennings, and Thurik (2010) highlight that the 'social innovation' school of thought insists on the skills needed for social entrepreneurship to be successful, and particularly on networking. Indeed, as mentioned above, social entrepreneurship requires to bridge multiple and diverse stakeholders (Alvord, Brown, and Letts 2004). Some scholars even consider this bridging skill as a distinguishing feature of social entrepreneurs, as compared to their commercial counterparts. For instance, Chell $(2007,17)$ states that "the very essence of social entrepreneurship is the capability to connect with social and community values, and through adept networking to realize their potential". Social entrepreneurs tend to rely more on interpersonal and wider networks than their commercial counterparts, who tend to rely on professional networks (Trivedi and Stokols 2011). Likewise, social entrepreneurs ensure a brokering role between diverse networks embodying different organizational fields, societal sectors, and logics (Myers and Nelson 2010).

Leadbeater (1997) argues that social entrepreneurs' social capital, that is, the value they can bring from their social network, constitutes their core asset. According to him, successful social entrepreneurs build wider networks through which they acquire ideas, people (hiring practices), and money. The higher social capital endowments of social enterprises as compared to commercial enterprises are empirically observed in a study on Spanish cooperatives and worker-owned companies. These tend to have more cooperation agreements and formal company links with local suppliers and customers than their traditional commercial counterparts (Bauer, Guzman, and Santos 2012).

The access to critical resources through networking is also underlined by other scholars, who insist on different aspects: knowledge (Hervieux and Turcotte 2010), overcoming resource deficiencies in a scarce-resource environment (Spear 2006), searching for a building or funding through strong ties and attracting employees and customers through weak ties (Sakurai 2008), and building credibility (Shaw and Carter 2007). Attempting to explain this link between network and resource acquisition, Meyskens, Carsrud, and Cardozo (2010) show that social ventures obtain resources from a social engagement network - i.e. a network in which the actors are committed to a specific social end. This social engagement network may turn into a symbiotic network in which resources are exchanged through a collaborative process for the development and growth of individuals and communities. Finally, in a single case study, Shepherd and Woods (2011) describe why securing resources through social networks may ultimately lead to successful social entrepreneurship as they observe that a reconfiguration of the social entrepreneur's social network and of the resources attached to it may ultimately lead to social innovation and sustainability of the social venture. 
Analysing the field of WISEs, Hulgård and Spear (2006) underline the importance of formal and informal networking for social enterprises. They argue that the multiple-stakeholder and multiplegoal structure of social enterprises implies a more intensive use of networking. In a qualitative study of five community-led non-profit organizations, Haugh (2007) also stresses the importance of two different types of network in the process of venture creation. She observes that two different social networks, i.e. an informal network and a tailor-made network, are mobilized throughout the six stages of community entrepreneurship _ (1) opportunity identification, (2) idea articulation, (3) idea ownership, (4) stakeholder mobilization, (5) opportunity exploitation, and (6) stakeholder reflection. She also finds that these networks evolve to help entrepreneurs access resources and to assist the progression from one stage to the next. Another classification of the types of networking that are critical for successful social entrepreneurship is offered by Purdue (2001), i.e. internal communal social capital (networking with a wide range of community groups) and external collaborative social capital (networking with partners from private and public sectors). With regard to the latter, the relationships with government are argued to be significant for success (Witkamp, Royakkers, and Raven 2011).

Sharir and Lerner (2006) and Marshall (2011) insist on the importance of building and using networks, especially through long-term cooperation relationships, for the social venture's success. They consider that networking skills, together with total dedication, are the necessary conditions for successful social entrepreneurship. Social networks are considered as one out of five constitutive dimensions of social entrepreneurship by Koe Hwee Nga and Shamuganathan (2010), along with social vision, sustainability, innovation, and financial returns. In their study on the personality traits of social entrepreneurs, they unsurprisingly find a positive relationship between agreeableness and social networks, and a negative relationship between neuroticism and social networks. Social networks are finally argued to be constitutive of social entrepreneurship because they can enhance human capacity to tackle complex problems such as social needs (Moore and Westley 2011).

Overall, putting efforts in building and mobilizing a supportive social network appears to be fundamental for the success of social entrepreneurship, especially due to the scarce-resource environment in which it develops and the multiple stakeholders it has to deal with. Hence, analyses at a micro-level observe that social entrepreneurs display specific traits and skills, as compared to their commercial counterparts. However, even though social networks may be employed in a different way in social entrepreneurship, using social networks as a means to an end is also a feature of commercial entrepreneurship (Hoang and Antoncic 2003). It seems, however, less frequent in the entrepreneurship literature to consider social networks as an end in itself, as it is observed in the following subsection.

\section{An Outcome or an Objective}

The fourth and last usage of the social network concept in the literature lies in the analysis of the outcomes and the goals of social entrepreneurship. Comparing social with commercial entrepreneurship, Trivedi and Stokols (2011) observe that both create social value for society but in different ways. Commercial entrepreneurship may provide job opportunities and infrastructure - that is, tied to economic value generation, whereas social entrepreneurship intends to create social value by addressing social problems and social needs through the mobilization of interpersonal and 
professional networks. Further, as social enterprises promote collaboration with other actors for diffusing the created social value, they contribute to the creation of social networks.

Some authors (e.g. Hulgård and Spear 2006; Praszkier and Nowak 2012) go one step further and argue that networking is an objective by itself for some social entrepreneurs as they carry out this activity at levels significantly above those that are needed for purely instrumental economic reasons. In this way, they aim to create social capital through some form of reciprocity with society. Similarly, Leadbeater (1997) argues that social entrepreneurship may have the creation of social capital (in the sense of Putnam [1995] and Fukuyama [2001]) as a goal, using networks for creating stronger bonds of trust and cooperation between the members of a community, thereby making it stronger. Drawing on action research in Israel, Friedman and Desivilya (2010) show that in divided societies, social entrepreneurship has to be integrated with conflict engagement to promote social inclusion. Ultimately, they argue that it may contribute to regional development by redefining relationships and social networks. Tracey, Phillips, and Jarvis (2011) also show how inter-individual and interorganizational networks are instrumental for social enterprises engaged in institutional entrepreneurship to promote their model at different levels of analysis.

Interestingly, in the sole - to our humble knowledge - quantitative simulation of social entrepreneurship in terms of social networks and interactions, Dal Forno and Merlone (2009) consider social entrepreneurs as acting as a catalyst for collaborative projects by creating or enforcing ties in the social network. They show that the structural position of social entrepreneurs influences the scale of the emerging collaborative project they can coordinate. Using also a complexity perspective, Baker, Onyx, and Edwards (2011) and Edwards and Baker (2013) consider social entrepreneurship as a dynamic within networks. They show that social entrepreneurship and social networks reinforce each other as social ties enable to access more resources and to expand social entrepreneurial activities. In turn, social entrepreneurship generates inter-network activities that expand social networks.

This fourth and last usage of the social network concept in the social entrepreneurship literature, i.e. creating social networks as an objective or an outcome of entrepreneurship, is probably a distinguishing feature of social entrepreneurship as compared to commercial entrepreneurship. Indeed, as social entrepreneurship often aims to foster cooperation, it stimulates the creation and the strengthening of social ties.

The literature review on social networks and social entrepreneurship has revealed four different usages of the concept, which are summarized in Table 1. It may be observed that, so far, the notion of social network has rather been used to describe - than to analyse - social entrepreneurship. Indeed, research has concentrated on how social entrepreneurs acquire resources, gain legitimacy, etc. In other words, the social network concept has been utilized to highlight distinguishing features of social entrepreneurship and to stress a critical factor of success. In addition, it has been used to describe some potential impact of social entrepreneurship. Yet the literature fails to contribute to understanding how social networks may explain the emergence of social entrepreneurship. To exploit the explanatory nature of social network theories, it is useful to examine their application in the conventional entrepreneurship literature so as to identify and adapt explanatory accounts to the context of social entrepreneurship.

$* * *$ INSERT TABLE $1 * * *$ 


\section{Social Networks and Entrepreneurship}

The literature on networks and entrepreneurship is abundant (Hoang and Antoncic 2003). Four theoretical frameworks or themes that are relevant avenues to understand the role of social networks in the emergence of social entrepreneurship have been identified. First, two of the three broad consequences of social networks on economic life identified by Smith-Doerr and Powell (2005) are developed, which are also relevant with regard to the emergence of entrepreneurship: resource distribution and diffusion of ideas. The third identified effect, which refers to the economic performance of individuals and organizations, is related to entrepreneurship stages subsequent to emergence and is thus not considered here. Then, the structural-hole argument is explored, looking especially at the density and homogeneity of the entrepreneur's social network. Finally, a theoretical framework of organization formation in terms of social network crystallization is presented. In parallel, each of these themes is translated into research proposals to be explored to better understand the social entrepreneurship emergence process.

\section{Resource Distribution}

Social networks influence the flow and the control of information. Consequently, an actor's access to resources depends on their position in the network and on the structure of their network. Looking at the negative side, a network can widen the gap between those who have access to resources and those who have not. Therefore, when discrimination excludes someone from the larger economy and from the mainstream network, for example, women and immigrants, they have to find alternatives to gain access to resources (Smith-Doerr and Powell 2005).

Following this argument, it is suggested that some collective entrepreneurship initiatives such as ethnic entrepreneurship arise from such disparities in resource distribution caused by exclusion from the broader social networks. In particular, ethnic entrepreneurship is said to emerge for such structural reasons, especially when they result in entry barriers on the labour market (Volery 2007). Indeed, economic exclusion tends to reinforce a group cohesiveness and thereby to create social capital for this group through a form of bounded solidarity. In other words, as a consequence of discrimination, ethnic social networks tend to be denser, i.e. with more and stronger ties between the actors of the network (Portes and Sensenbrenner 1993). Ethnic entrepreneurs are said to rely on this stronger network to identify opportunities and to obtain valued resources for exploiting these opportunities (Aldrich and Waldinger 1990).

In social entrepreneurship, the central concern is to address unmet social needs, due to market and government failures. These needs may stem from the exclusion of the economy, such as barriers to enter the labour market or to get access to health (Monllor 2010). The perception of entry barriers by social entrepreneurs in certain markets is shown to significantly influence social entrepreneurship opportunity recognition (Robinson 2006). Besides the exclusion argument, Defourny and Delvetere (1999) identify two driving forces to the development of social enterprises: a condition of necessity and a sense of belonging to a social group sharing a collective identity and destiny. This cohesiveness is also particularly present in community entrepreneurship (Johannisson 1990). Future research could therefore draw on the analogy with ethnic entrepreneurship and the role of social networks of individuals and groups who are excluded from the economy, who share a common identity and who 
collaborate to form new social ventures (as is the case, for instance, in agricultural cooperatives involved in fair trade). In particular, the following research proposal is put forward.

Research proposal 1: Dense networks (i.e. enclaves) formed by solidarity among marginalized individuals are a fertile ground for the emergence of social entrepreneurship, as a means for these individuals to get alternative access to resources.

\section{Diffusion of ldeas}

The literature on entrepreneurship and innovation dealing with social networks also insists on issues related to the diffusion of information and ideas that may trigger entrepreneurial opportunities. Indeed, interpersonal networks are very efficient communication channels for spreading new ideas. It is observed that ideas tend to diffuse faster and better within dense networks and an individual's position in the network will strongly influence whether they have access to the information that leads to innovation. For example, Coleman, Katz, and Menzel (1957) observe that physicians with a dense network of relationships and who occupy a central position do faster adopt innovations in drug prescription. Interpersonal and inter-organizational ties also influence the diffusion of business models and strategies. The networks from which information can be captured are very diverse and include trade associations, alumni of a university, organizations along a supply chain, etc. The actors that are most likely to identify entrepreneurial opportunities and to adopt innovation earlier than others are located at the intersection of numerous networks. Such a position enables them to link to diverse sources, which may trigger more new ideas that they will be able to test in their networks (Smith-Doerr and Powell 2005).

While the diffusion of social innovation and socially entrepreneurial models has been studied using a (neo-)institutional theoretical approach (e.g. Nicholls and Cho 2006; Nicholls 2010a, 2010b; Huybrechts 2010), there has been a lack of social network perspective despite the fact that social networks are argued to influence opportunity recognition and exploitation in social entrepreneurship (Datta and Jessup 2009; Monllor 2010) and social entrepreneurs are often found to have social proximity to the social need they want to tackle (Germak and Robinson 2013). Haugh (2007) merely recognizes that social interactions help members of a community who have an idea for community entrepreneurship to share their enthusiasm with other members in order to mobilize them to create a venture. Therefore, future research should look at the networks of nascent social entrepreneurs and examine whom they get their information from, as well as how they identified a social entrepreneurial opportunity and evaluated it in relation to their position in the social network.

More precisely, the following proposal is put forward.

Research proposal 2: Greater connectivity, among others through new technologies, is a driver of social entrepreneurship emergence by increasing awareness of the social needs and of social opportunities.

\section{Structural Holes, Density, and Heterogeneity}

Because information flows through social networks, controlling the information flow by having a central position in a large, heterogeneous, and sparse network is likely to generate entrepreneurial opportunities. To some extent, this argument may oppose the themes explored above. Burt (1992) suggests that structural holes constitute such opportunities for controlling information and 
resources. Structural holes are the voids between unconnected subparts of the social network. An entrepreneur who bridges the previously unconnected parts of the network may decide upon the information to transmit to one or to the other part of the network they bridge. Therefore, the entrepreneur has knowledge that is not available to others, which they might exploit. It is argued that the more unconstrained the ties of an entrepreneur are - that is, the more sparse the network is, the more benefits they can take out of bridging these ties (Aldrich 2005). This argument is, however, nuanced for actors from minorities (female, immigrants) who need to rely more heavily on strong ties to get access to valued resources (Ibarra 1995). As discussed previously, they may turn barriers to access the valued resources into opportunities through the formation of alternative networks.

The argument is augmented by Burt (2004) himself by demonstrating that people connecting different groups, that is, those who bridge structural holes, are more likely to have 'good ideas' because they are more familiar with alternative ways of thinking and behaving. Indeed, he observes that opinion and behaviour are more homogeneous within than between groups. Hence, brokering between groups offers the possibility to select or synthetize and to generate ideas that are valued by all groups, which are thus considered to be 'good ideas' (Burt 2004). More recent studies validate this proposition and show that structural holes are linked to creativity and innovativeness (Rodan 2010) and have a strong positive effect on performance (Aarstad 2012). In their study on the origin of structural holes, Zaheer and Soda (2009) nuance this relationship by showing that homogeneity rather than diversity in the network content enhances performance because it allows the creation of efficiency routines. The diversity argument has also been put at stake in a study on entrepreneurial team - or founding team - formation. More similar people will form an entrepreneurial team to lower the perceived risk of entrepreneuring. Hence, it is in a homogeneous network that entrepreneurial teams emerge (Ruef, Aldrich, and Carter 2003). Besides heterogeneity, a sparse network as being a critical dimension for the emergence of entrepreneurship is also challenged. Indeed, as described in the previous subsection, the diffusion of ideas and innovation tends to go faster in dense networks.

So far, the structural-hole argument has not been tested formally in a social entrepreneurship context, which opens the door to fruitful research. The social entrepreneur is often considered as a bridge-builder between different sectors or spheres of activity (Nyssens 2006; Pache and Chowdhury 2012). Hence, it is likely that this brokering role also happens between unconnected parts of the social network. Further, when social entrepreneurship aims to create social ties and to foster collaboration, it bridges previously unconnected actors and attempts to coordinate their action (Dal Forno and Merlone 2009). Therefore, future research should look at the structural position of social entrepreneurs and evaluate whether centrality in a heterogeneous network fosters social entrepreneurship. Further, in an attempt to reconcile the divergent views on the role of network density in triggering entrepreneurship, evaluating whether different social networks foster different types of social entrepreneurship can constitute a promising avenue for research. From what precedes, the following proposal can be drawn.

Research proposal 3: The bridging of different logics (market, social welfare, etc.) and different networks may constitute an opportunity for new solutions to social needs and hence driving social entrepreneurship.

Crystallization of the Network 
Analysing networks and entrepreneurship in a processual way, Larson and Starr (1993) present a network model of organization formation in a widely cited but barely empirically tested article (Hoang and Antoncic 2003; Slotte-Kock and Coviello 2010). The authors argue that the simple and idiosyncratic personalized relationships of the entrepreneur transform into a network of stable, multidimensional inter-organizational exchange relationships through three stages. The crystallization of those simple and complex relationships results in organization formation. Likewise, Johannisson and Olaison (2007) state that 'ventures crystallize out of personal networks, where relations are as much existentially as instrumentally defined, practised as much for crafting individual and collective identity as for actualizing new undertakings' (58). It should be noted that this notion of crystallization of the network is also used to characterize the formation of entrepreneurial teams (Chabaud and Condor 2009).

First, the entrepreneur identifies, through a trial-and-error process, existing social ties - or dyads that will provide the necessary resources for starting the venture. These relationships are one dimensional and have either a social/affective or an economic/instrumental ground. Therefore, family, friends, and prior professional contacts are selected by the entrepreneur to enter in a relational contract that is based on expectations and norms, which are set in function of the relationship's history. It should be stressed that new opportunistic contacts may also be identified during this stage. Empirical studies show that pre-existing social ties are fundamental in the early stages of the entrepreneurial process (Birley 1985; Dubini and Aldrich 1991).

During the second stage, the entrepreneur attempts to transform these dyadic, one-dimensional exchange relationships into multiplex relationships mixing instrumental and social orientations. These socioeconomic exchange relationships are characterized by trust and reciprocity, as both the entrepreneur and their counterpart are concerned to maintain their reputation. This evolution of the network is observed by Newbert and Tornikoski (2012).

The third stage is characterized by the further complexity of the relationships, among others, by adding business functions to them. Besides, more information is exchanged between the partners and the interaction is routinized. Even though the relationships are managed by individuals, the exchanges shift to an increasingly organizational level. According to Larson and Starr (1993), the successful outcome of these three stages is the crystallization of a critical mass of stable, committed, revenue-generating, inter-organizational exchange relationships into a new organization that will be characterized by stability and predictability. This stability stems from the perception of participants that their long-term commitment to build strong socioeconomic ties with the entrepreneur involves high switching costs. The process goes on as the newly formed crystallized organization expands its network and leverages new resources by showing how effectively it can mobilize critical resources to generate revenues.

This evolution of network is exemplified in a longitudinal study on community-led entrepreneurship, in which Haugh (2007) observes that the daily interactions within the community create opportunities for individuals with ideas to share them with other members of the community and to attempt to mobilize them. As a growing number of individuals are involved, more formal arrangements are set up (specific meetings, boundary settings of the organization, etc.). She highlights that the strong ties within the community and the weak ties with formal organizations are involved in the early stages of the organization formation. In later stages, members are included in or 
discarded off the network depending on the value they add and on their ability to contribute to meet specific resource requirements.

As social entrepreneurship sometimes results from the collaboration of actors to achieve a social aim (Hervieux and Turcotte 2010) and tends to evolve into multi-stakeholder governance models, it could probably constitute an insightful domain of investigation for Larson and Starr's framework. The following proposal is suggested.

Research proposal 4: The coalition of a series of actors brought together by social needs may trigger social entrepreneurship through the cohesion acquired from their commitment to achieving a social goal.

To sum up, it has been observed that entrepreneurship may emerge as a result of distributional disparities, of ideas diffused through the network, of structural-hole bridging, and through crystallization of the social network. These four themes have each led us to formulate a research proposal to examine the emergence process of social entrepreneurship. Table 2 summarizes the four themes and associated research proposals using social networks in the context of social entrepreneurship emergence.

$* * *$ INSERT TABLE $2 * * *$

\section{Conclusion}

This study acknowledges the lack of explanation for how and why social entrepreneurship arises, and argues that the sociology of social networks offers valuable insights and promising research avenues. The extant literature on social entrepreneurship dealing with social networks reveals four different usages of the latter concept. Although these usages do not fundamentally differ from usages made in the traditional entrepreneurship literature, studies seem to show different results within the broad categories. First, both types of entrepreneurship are said to be embedded in a broader social context. Social entrepreneurship, because it addresses social needs and deals with numerous stakeholders, is likely to exhibit stronger embeddedness than traditional entrepreneurship. Second, social networks and collective entrepreneurship is a theme that seems to appear more frequently in the social entrepreneurship literature, even though the figure of the heroic lone social entrepreneur remains frequent (e.g. Hemingway 2005). This should not be surprising as social enterprise forms tend to integrate a collective dimension in their structure (e.g. cooperative) and some types of social entrepreneurship are collective by nature (e.g. community entrepreneurship). Third, networking is considered as a critical skill or a fundamental activity of traditional and social entrepreneurship. Nevertheless, it is argued that it is even more critical in social entrepreneurship, given the scarceresource environment in which it develops and the need to connect with multiple stakeholders. The fourth usage, i.e. creating social networks as an objective or an outcome of entrepreneurship, is probably singular to social entrepreneurship. Indeed, as social entrepreneurship often aims to foster cooperation, it stimulates the creation and the strengthening of social ties within a community. This review of the social entrepreneurship literature revealed that the social network concept is used in a descriptive rather than explanatory way. Indeed, social networks are little used so far to explain the emergence of social entrepreneurship. 
This is why the traditional (commercial) entrepreneurship literature proves useful to identify theoretical arguments related to the role of social networks in explaining the emergence of social entrepreneurship. First, distributional issues and exclusion from the economy are considered to foster ethnic entrepreneurship through a stronger distinct network. Using this argument, it has been suggested here that social entrepreneurship may result from the cooperation efforts of individuals who are discriminated and set aside from the society and the economy. Then, the better and faster diffusion of information achieved through greater network density increases awareness of opportunities. In the same way, our research proposal suggests social entrepreneurship to emerge from higher awareness to social needs and social opportunities developed, thanks to greater connectivity. Third, the structural-hole argument shows how entrepreneurs may be understood as brokers between unconnected parts of the network. It was suggested to consider social entrepreneurship as emerging from bridge-building between several logics, borne by previously unconnected networks. Finally, Larson and Starr's (1993) network model of organization formation has been suggested of particular interest to social entrepreneurship research as it entails the participation of multiple stakeholders in entrepreneurship emergence. In particular, it may be concluded that as social networks focused on addressing social needs grow and formalize, they may crystallize to form a socially oriented venture.

Overall, this article paves the way for a stronger integration of extant knowledge on social networks in a social entrepreneurship setting. This integration leads to a future research agenda that consists of four research proposals using social networks to explain social entrepreneurship emergence. This agenda is consistent with other calls for a stronger integration of extant organization theories in the study of social entrepreneurship (e.g. Nicholls and Cho 2006; Dacin, Dacin, and Matear 2010). Our research proposals can also help social entrepreneurship practitioners and support structures to better grasp the different ways through which social networks can be mobilized and stimulated as a resource and as an opportunity to bring about socially entrepreneurial collective processes. This could lead to a stronger emphasis on social networks and collective entrepreneurial dimensions in discourses on support measures for social entrepreneurship. Hence, scholars should be encouraged both to empirically investigate the research proposals set out here and to translate their findings into concrete recommendations for running and supporting social enterprises.

\section{References}

Aarstad, J., 2012. Do structural holes and network connectivity really affect entrepreneurial performance? The Journal of Entrepreneurship, 21(2), 253-268.

Aldrich, H. E., 2005. Entrepreneurship. In: Smelser, N. J. and Swedberg, R. eds. The handbook of economic sociology. New York: Russel Sage Foundation, 451-477.

Aldrich, H. E. and Waldinger, R., 1990. Ethnicity and entrepreneurship. Annual Review of Sociology, 16, 111-135.

Alvord, S. H., Brown, L. D. and Letts, C. W., 2004. Social entrepreneurship and societal transformation: An exploratory study. Journal of Applied Behavioral Science, 40(3), 260-282.

Anheier, H. K., 2005. Nonprofit organizations: Theory, management, policy. London: Routledge. 
Arenius, P. and Laitinen, K., 2011. Entrepreneurial teams and the evolution of networks: A longitudinal study. The International Journal of Entrepreneurship and Innovation, 12(4), 239-247.

Austin, J., Stevenson, H. and Wei-Skillern, J., 2006. Social and commercial entrepreneurship: Same, different, or both? Entrepreneurship Theory and Practice, 30(1), 1-22.

Bacq, S. and Janssen, F., 2011. The multiple faces of social entrepreneurship: A review of definitional issues based on geographical and thematic criteria. Entrepreneurship \& Regional Development, 23(5/6), 373-403.

Badelt, C., 1997. Entrepreneurship theories of the non-profit sector. Voluntas, 8(2), 162-178.

Baker, E., Onyx, J. and Edwards, M., 2011. Emergence, social capital and entrepreneurship: Understanding networks from the inside. Emergence: Complexity \& Organization, 13(3), 21-38.

Battilana, J. and Dorado, S., 2010. Building sustainable hybrid organizations: The case of commercial microfinance organizations. Academy of Management Journal, 53(6), 1419-1440.

Bauer, C. M., Guzmán, C. and Santos, F. J., 2012. Social capital as a distinctive feature of Social Economy firms. International Entrepreneurship and Management Journal, 8(4), 437-448.

Beckert, J., 2009. The great transformation of embeddedness: Karl Polanyi and the new economic sociology. In: Hann, C. and Hart, K. eds. Market and Society: The Great Transformation Today. Cambridge: Cambridge University Press, 38-55.

Ben-Ner, A. and Van Hoomissen, T., 1991. Nonprofit organizations in the mixed economy: A demand and supply analysis. Annals of Public and Cooperative Economics, 62(4), 519-550.

Bidart, C., Degenne, A. and Grossetti, M., 2011. La vie en réseau : Dynamique des relations sociales [Life in network: Social relations dynamics]. Paris: Presses Universitaires de France.

Bilodeau, M. and Slivinski, A., 1998. Rational nonprofit entrepreneurship. Journal of Economics \& Management Strategy, 7(4), 551-571.

Birley, S., 1985. The role of networks in the entrepreneurial process. Journal of Business Venturing, 1(1), 107-117.

Borzaga, C. and Defourny, J., eds., 2001. The emergence of social enterprise. London: Routledge.

Bourdieu, P., 1980. Le capital social [Social capital]. Actes de la recherche en sciences sociales, 31(Jan. 1980), 2-3.

Burt, R. S., 1992. Structural holes: The social structure of competition. Cambridge, MA: Harvard University Press.

Burt, R. S., 2004. Structural holes and good ideas. American Journal of Sociology, 110(2), 349-399.

Busch, C., 2014. Substantiating social entrepreneurship research: Exploring the potential of integrating social capital and networks approaches. International Journal of Entrepreneurial Venturing, 6(1), 69-84. 
Cajaiba-Santana, G., 2010. Socially constructed opportunities in social entrepreneurship: A structuration model. In: Fayolle, A. and Matlay, H. eds. Handbook of research in Social entrepreneurship. Cheltenham: Edward Elgar, 88-106.

Calton, J. M., et al., 2013. Building partnerships to create social and economic value at the base of the global development pyramid. Journal of Business Ethics, 117(4), 721-733.

Campi, S., Defourny, J. and Grégoire, O., 2006. Work integration social enterprises: Are they multiplegoal and multi-stakeholder organizations? In: Nyssens, M. ed. Social enterprise: At the crossroads of market, public policies and civil society. London: Routledge, 29-49.

Certo, S. T. and Miller, T. L., 2008. Social entrepreneurship: Key issues and concepts. Business Horizons, 51(4), 267-271.

Chabaud, D. and Condor, R., 2009. La formation des équipes entrepreneuriales : Une étude exploratoire [Entrepreneurial team formation: An exploratory study]. Revue internationale P.M.E., 22(1), 81-102.

Chabaud, D. and Messeghem, K., 2012. Le paradigme de l'opportunité : Des fondements à la refondation [The paradigm of opportunity: From groundworks to refounding]. Revue française de gestion, (206), 93-112.

Chell, E., 2007. Social enterprise and entrepreneurship: Towards a convergent theory of the entrepreneurial process. International Small Business Journal, 25(1), 5-26.

Coleman, J., Katz, E. and Menzel, H., 1957. The diffusion of an innovation among physicians. Sociometry, 20(4), 253-270.

Coleman, J. S., 1988. Social capital in the creation of human capital. American Journal of Sociology, 94, S95-S120.

Corner, P. D. and Ho, M., 2010. How opportunities develop in social entrepreneurship. Entrepreneurship Theory and Practice, 34(4), 635-659.

Dacin, M. T., Beal, B. D. and Ventresca, M. J., 1999. The embeddedness of organizations: Dialogue \& directions. Journal of Management, 25(3), 317-356.

Dacin, P. A., Dacin, M. T. and Matear, M., 2010. Social entrepreneurship: Why we don't need a new theory and how we move forward from here. Academy of Management Perspectives, 24(3), 37-57.

Dal Forno, A. and Merlone, U., 2009. Social entrepreneurship effects on the emergence of cooperation in networks. Emergence: Complexity \& Organization, 11(4), 48-58.

Datta, A. and Jessup, L., 2009. Expanding opportunities in a shrinking world: A conceptual model explicating the role of social networks and Internet-based virtual environments in social entrepreneurship. International Journal of Virtual Communities and Social Networking, 1(4), 33-49.

Davidsson, P. and Wiklund, J., 2001. Levels of analysis in entrepreneurship research: Current research practice and suggestions for the future. Entrepreneurship Theory and Practice, 25(4), 81-100. 
Defourny, J., 2001. Introduction: From third sector to social enterprise. In: Borzaga, C. and Defourny, J. eds. The emergence of social enterprise. London: Routledge, 1-28.

Defourny, J. and Delvetere, P., 1999. The social economy: The worldwide making of a third sector. In: Defourny, J., Delvetere, P. and Fonteneau, B. eds. L'économie sociale au Nord et au Sud. Bruxelles: De Boeck, 25-56.

Dey, P., 2013. Governing the social through 'social entrepreneurship': A Foucauldian view on 'the art of governing' in advanced liberalism. In: Douglas, H. and Grant, S. eds. Social entrepreneurship and enterprises: Concepts in context. Melbourne: Tilde University Press, 55-72.

Dey, P. and Steyaert, C., 2010. The politics of narrating social entrepreneurship. Journal of Enterprising Communities: People and Places in the Global Economy, 4(1), 85-108.

Doherty, B., Haugh, H. and Lyon, F., 2014. Social Enterprises as Hybrid Organizations: A Review and Research Agenda. International Journal of Management Reviews, n/a-n/a.

Dorado, S. and Ventresca, M. J., 2013. Crescive entrepreneurship in complex social problems: Institutional conditions for entrepreneurial engagement. Journal of Business Venturing, 28(1), 69-82.

Dubini, P. and Aldrich, H. E., 1991. Personal and extended networks are central to the entrepreneurial process. Journal of Business Venturing, 6(5), 305-313.

Edwards, M. and Baker, E., 2013. Construction in human interaction dynamics: Organizing mechanisms, strategic ambiguity and interpretive dominance. Emergence: Complexity \& Organization, 15(4), 21-36.

Friedman, V. J. and Desivilya, H., 2010. Integrating social entrepreneurship and conflict engagement for regional development in divided societies. Entrepreneurship \& Regional Development, 22(6), 495514.

Frisby, D., 2002. Georg Simmel (revised ed.). New York: Routledge.

Fukuyama, F., 2001. Social capital, civil society and development. Third World Quarterly, 22(1), 7-20.

Gardin, L., 2006. A variety of resource mixes inside social enterprises. In: Nyssens, M. ed. Social enterprise: At the crossroads of market, public policies and civil society. London: Routledge, 111-135.

Gedajlovic, E., et al., 2013. Social capital and entrepreneurship: A schema and research agenda. Entrepreneurship Theory and Practice, 37(3), 455-478.

Germak, A. J. and Robinson, J. A., 2013. Exploring the motivation of nascent social entrepreneurs. Journal of Social Entrepreneurship, 5(1), 5-21.

Granovetter, M., 1973. The strength of weak ties. American Journal of Sociology, 78(6), 1360-1380.

Granovetter, M., 1985. Economic action and social structure: The problem of embeddedness. American Journal of Sociology, 91(3), 481-510.

Granovetter, M., 2005. The impact of social structure on economic outcomes. Journal of Economic Perspectives, 19(1), 35-50. 
Haugh, H., 2005. A research agenda for social entrepreneurship. Social Enterprise Journal, 1(1), 1-12.

Haugh, H., 2007. Community-led social venture creation. Entrepreneurship Theory and Practice, 31(2), 161-182.

Hemingway, C. A., 2005. Personal values as a catalyst for corporate social entrepreneurship. Journal of Business Ethics, 60(3), 233-249.

Hervieux, C. and Turcotte, M.-F. B., 2010. Social entrepreneurs' actions in networks. In: Fayolle, A. and Matlay, H. eds. Handbook of research in Social entrepreneurship. Cheltenham: Edward Elgar, 182-201.

Hoang, H. and Antoncic, B., 2003. Network-based research in entrepreneurship: A critical review. Journal of Business Venturing, 18(2), 165-187.

Hoogendoorn, B., Pennings, E. and Thurik, R., 2010. What do we know about social entrepreneurship? An analysis of empirical research. International Review of Entrepreneurship, 8(2), 71-112.

Hulgård, L. and Spear, R., 2006. Social enterpreneurship and the mobilization of social capital in European social enterprises. In: Nyssens, M. ed. Social enterprise: At the crossroads of market, public policies and civil society. London: Routledge, 85-108.

Huybrechts, B., 2012. Fair trade organizations and social enterprise: Social innovation through hybrid organization models. New York: Routledge.

Huybrechts, B. and Mertens, S., 2014. The relevance of the cooperative model in the field of renewable energy. Annals of Public and Cooperative Economics, 85(2).

Huybrechts, B., Mertens, S. and Rijpens, J., 2014. Explaining stakeholder involvement in social enterprise governance through resources and legitimacy. In: Defourny, J., Hulgård, L. and Pestoff, V. eds. Social Enterprise and the Third Sector: Changing European Landscapes in a Comparative Perspective. New York: Routledge.

Huybrechts, B. and Nicholls, A., 2012. Social entrepreneurship: Definitions, drivers and challenges. In: Volkmann, C. K., Tokarski, K. O. and Ernst, K. eds. Social entrepreneurship and social business: An introduction and discussion with case studies. Wiesbaden, Germany: Springer-Gabler, 31-48.

Ibarra, H., 1995. Race, opportunity, and diversity of social circles in managerial networks. Academy of Management Journal, 38(3), 673-703.

Johannisson, B., 1990. Community entrepreneurship - cases and conceptualization. Entrepreneurship \& Regional Development, 2(1), 71-88.

Johannisson, B. and Olaison, L., 2007. The moment of truth - Reconstructing entrepreneurship and social capital in the eye of the storm. Review of Social Economy, 65(1), 55-78.

Kadushin, C., 1995. Friendship among the French financial elite. American Sociological Review, 60(2), 202-221. 
Khavul, S. and Bruton, G. D., 2013. Harnessing innovation for change: sustainability and poverty in developing countries. Journal of Management Studies, 50(2), 285-306.

Kistruck, G. M. and Beamish, P. W., 2010. The interplay of form, structure, and embeddedness in social intrapreneurship. Entrepreneurship Theory and Practice, 34(4), 735-761.

Koe Hwee Nga, J. and Shamuganathan, G., 2010. The influence of personality traits and demographic factors on social entrepreneurship start up intentions. Journal of Business Ethics, 95(2), 259-282.

Korsgaard, S., 2011. Opportunity formation in social entrepreneurship. Journal of Enterprising Communities: People and Places in the Global Economy, 5(4), 265-285.

Larson, A. and Starr, J. A., 1993. A network model of organization formation. Entrepreneurship Theory and Practice, 17(2), 5-15.

Laville, J.-L., Lemaître, A. and Nyssens, M., 2006. Public policies and social enterprises in Europe: The challenge of institutionalization. In: Nyssens, M. ed. Social enterprise: At the crossroads of market, public policies and civil society. London: Routledge, 272-295.

Laville, J.-L. and Nyssens, M., 2001. The social enterprise: Towards a theoretical socio-economic approach. In: Borzaga, C. and Defourny, J. eds. The emergence of social enterprise. London:

Routledge, 312-332.

Leadbeater, C., 1997. The rise of the social entrepreneur. London: Demos.

Lehner, O. M. and Kaniskas, J., 2012. Opportunity recognition in social entrepreneurship: A thematic meta analysis. The Journal of Entrepreneurship, 21(1), 25-58.

Lin, N., 2001. Social capital: A theory of social structure and action. Cambridge: Cambridge University Press.

Lumpkin, G. T., et al., 2013. Entrepreneurial processes in social contexts: How are they different, if at all? Small Business Economics, 40(3), 761-783.

Mair, J. and Martí, I., 2006. Social entrepreneurship research: A source of explanation, prediction, and delight. Journal of World Business, 41(1), 36-44.

Mair, J. and Noboa, E., 2006. Social entrepreneurship: How intentions to create a social venture are formed. In: Mair, J., Robinson, J. and Hockerts, K. eds. Social entrepreneurship. New York: Palgrave MacMillan, 121-135.

Marshall, R. S., 2011. Conceptualizing the international for-profit social entrepreneur. Journal of Business Ethics, 98(2), 183-198.

Mercklé, P., 2004. Sociologie des réseaux sociaux [Sociology of social networks]. Paris: Editions La Découverte.

Meyskens, M., Carsrud, A. L. and Cardozo, R. N., 2010. The symbiosis of entities in the social engagement network: The role of social ventures. Entrepreneurship \& Regional Development, 22(5), 425-455. 
Monllor, J., 2010. Social entrepreneurship: A study on the source and discovery of social opportunities. In: Hockerts, K., Mair, J. and Robinson, J. eds. Values and opportunities in social entrepreneurship. New York: Palgrave Macmillan, 99-120.

Montgomery, A. W., Dacin, P. A. and Dacin, M. T., 2012. Collective social entrepreneurship: Collaboratively shaping social good. Journal of Business Ethics, 111(3), 375-388.

Moore, M.-L. and Westley, F., 2011. Surmountable chasms: Networks and social innovation for resilient systems. Ecology and Society [online], 16 (1). Available from:

http://www.ecologyandsociety.org/vol16/iss1/art5/ [Accessed May 23, 2013].

Myers, P. and Nelson, T., 2010. Considering social capital in the context of social entrepreneurship. In: Fayolle, A. and Matlay, H. eds. Handbook of research in Social entrepreneurship. Cheltenham: Edward Elgar, 271-285.

Newbert, S. L. and Tornikoski, E. T., 2012. Supporter networks and network growth: a contingency model of organizational emergence. Small Business Economics, 39(1), 141-159.

Nicholls, A., 2010a. The institutionalization of social investment: The interplay of investment logics and investor rationalities. Journal of Social Entrepreneurship, 1(1), 70-100.

Nicholls, A., 2010b. The legitimacy of social entrepreneurship: Reflexive isomorphism in a preparadigmatic field. Entrepreneurship Theory and Practice, 34(4), 611-633.

Nicholls, A. and Cho, A. H., 2006. Social entrepreneurship: The structuration of a field. In: Nicholls, A. ed. Social entrepreneurship: New models of sustainable social change. Oxford: Oxford University Press, 99-118.

Nyssens, M., ed., 2006. Social enterprise: At the crossroads of market, public policies and civil society. London: Routledge.

Pache, A.-C. and Chowdhury, I., 2012. Social entrepreneurs as institutionally embedded entrepreneurs: Toward a new model of social entrepreneurship education. Academy of Management Learning \& Education, 11(3), 494-510.

Polanyi, K., 1944/2001. The political and economic origins of our time (2nd ed.). Boston: Beacon Press.

Portes, A., 1998. Social capital: Its origins and applications in modern sociology. Annual Review of Sociology, 24, 1-24.

Portes, A. and Sensenbrenner, J., 1993. Embeddedness and immigration: Notes on the social determinants of economic action. American Journal of Sociology, 98(6), 1320-1350.

Praszkier, R. and Nowak, A., 2012. Social entrepreneurship: Theory and practice. New York: Cambridge University Press.

Purdue, D., 2001. Neighbourhood governance: Leadership, trust and social capital. Urban Studies, 38(12), 2211-2224. 
Putnam, R. D., 1995. Bowling alone: America's declining social capital. Journal of Democracy, 6(1), 6578.

Robinson, J., 2006. Navigating social and institutional barriers to markets: How social entrepreneurs identify and evaluate opportunities. In: Mair, J., Robinson, J. and Hockerts, K. eds. Social entrepreneurship. New York: Palgrave MacMillan, 95-120.

Rodan, S., 2010. Structural holes and managerial performance: Identifying the underlying mechanisms. Social Networks, 32(3), 168-179.

Ruef, M., Aldrich, H. E. and Carter, N. M., 2003. The structure of founding teams: Homophily, strong ties, and isolation among U.S. entrepreneurs. American Sociological Review, 68(2), 195-222.

Sakurai, M., 2008. Social entrepreneurs and resource mobilization: The role of social capital. 8th ISTR International Conference and 2nd EMES-ISTR European Conference. Barcelona, Spain.

Santos, F. M., 2012. A positive theory of social entrepreneurship. Journal of Business Ethics, 111(3), 335-351.

Schieb-Bienfait, N., Charles-Pauvers, B. and Urbain, C., 2009. Emergence entrepreneuriale et innovation sociale dans l'économie sociale et solidaire : Acteurs, projets et logiques d'action [Entrepreneurial emergence and social innovation in the social and solidarity economy: Actors, projects and logics of action]. Innovations, (30), 13-39.

Scott, J., 2000. Social network analysis: A handbook (2nd ed.). London: Sage.

Seelos, C., et al., 2011. The embeddedness of social entrepreneurship: Understanding variation across local communities. In: Marquis, C., Lounsbury, M. and Greenwood, R. eds. Communities and Organizations. Emerald Group Publishing Limited, 333-363.

Sharir, M. and Lerner, M., 2006. Gauging the success of social ventures initiated by individual social entrepreneurs. Journal of World Business, 41(1), 6-20.

Shaw, E. and Carter, S., 2007. Social entrepreneurship: Theoretical antecedents and empirical analysis of entrepreneurial processes and outcomes. Journal of Small Business and Enterprise Development, 14(3), 418-434.

Shepherd, D. and Woods, C., 2011. Developing digital citizenship for digital tots: Hector's World Limited. Emergence: Complexity \& Organization, 13(3), 1-20.

Short, J. C., Moss, T. W. and Lumpkin, G. T., 2009. Research in social entrepreneurship: Past contributions and future opportunities. Strategic Entrepreneurship Journal, 3(2), 161-194.

Simmel, G., 1909. The problem of sociology (translated and annotated by Albion W. Small). American Journal of Sociology, 15(3), 289-320.

Slotte-Kock, S. and Coviello, N., 2010. Entrepreneurship research on network processes: A review and ways forward. Entrepreneurship Theory and Practice, 34(1), 31-57. 
Smith-Doerr, L. and Powell, W. W., 2005. Networks and economic life. In: Smelser, N. J. and Swedberg, R. eds. The handbook of economic sociology. New York: Russel Sage Foundation, 379-402.

Smith, B. R. and Stevens, C. E., 2010. Different types of social entrepreneurship: The role of geography and embeddedness on the measurement and scaling of social value. Entrepreneurship \& Regional Development, 22(6), 575-598.

Spear, R., 2006. Social entrepreneurship: A different model? International Journal of Social Economics, 33(5/6), 399-410.

Spear, R., 2012. Innovation and collective entrepreneurship. Universitas Forum: International Journal on Human Development and International Cooperation [online], 3 (2). Available from: http://www.universitasforum.org/index.php/ojs/article/view/123 [Accessed 02/02/2013].

Steinberg, R., 2006. Economic theories of nonprofit organizations. In: Powell, W. W. and Steinberg, R. eds. The nonprofit sector: A research handbook (2nd ed.). New Haven: Yale University Press, 117-139.

Thompson, J. and Doherty, B., 2006. The diverse world of social enterprise: A collection of social enterprise stories. International Journal of Social Economics, 33(5/6), 361-375.

Tracey, P., Phillips, N. and Jarvis, O., 2011. Bridging Institutional Entrepreneurship and the Creation of New Organizational Forms: A Multilevel Model. Organization Science, 22(1), 60-80.

Trivedi, C. and Stokols, D., 2011. Social enterprises and corporate enterprises: Fundamental differences and defining features. Journal of Entrepreneurship, 20(1), 1-32.

Volery, T., 2007. Ethnic entrepreneurship: A theoretical framework. In: Dana, L. P. ed. Handbook of research on ethnic minority entrepreneurship. Cheltenham: Edward Elgar Publishing, 30-41.

Wasserman, S. and Faust, K., 1994. Social network analysis: Methods and applications. New York: Cambridge University Press.

Witkamp, M. J., Royakkers, L. M. M. and Raven, R. P. J. M., 2011. From cowboys to diplomats: Challenges for social entrepreneurship in the Netherlands. Voluntas, 22(2), 283-310.

Zaheer, A. and Soda, G., 2009. Network evolution: The origins of structural holes. Administrative Science Quarterly, 54(1), 1-31. 
Table 1. Four uses of the social network concept with different foci and contributions to understand social entrepreneurship

\begin{tabular}{lll}
\hline Usage & $\begin{array}{l}\text { Focus with } \\
\text { regard to social } \\
\text { entrepreneurship }\end{array}$ & Contribution \\
\hline $\begin{array}{l}\text { Embeddedness of social } \\
\text { entrepreneurship }\end{array}$ & $\begin{array}{l}\text { Distinguishing } \\
\text { feature }\end{array}$ & $\begin{array}{l}\text { Understanding social entrepreneurship in } \\
\text { the relationships it has with other sectors } \\
\text { of activity and with other actors of } \\
\text { society. }\end{array}$ \\
\hline $\begin{array}{l}\text { Collective social } \\
\text { entrepreneurship }\end{array}$ & $\begin{array}{l}\text { Distinguishing } \\
\text { feature }\end{array}$ & $\begin{array}{l}\text { Understanding social entrepreneurship as } \\
\text { undertaken by a coalition of actors, in a } \\
\text { collective dynamics. }\end{array}$ \\
\hline $\begin{array}{l}\text { Critical skill for success or } \\
\text { fundamental activity of social } \\
\text { entrepreneurship }\end{array}$ & $\begin{array}{l}\text { Condition for } \\
\text { success }\end{array}$ & $\begin{array}{l}\text { Understanding the individual ability to } \\
\text { build and mobilise a supportive social } \\
\text { network as a factor of success. }\end{array}$ \\
\hline $\begin{array}{l}\text { Outcome or objective of } \\
\text { social entrepreneurship }\end{array}$ & Impact & $\begin{array}{l}\text { Understanding the impact of social } \\
\text { entrepreneurship in terms of social capital } \\
\text { for society. }\end{array}$ \\
\hline
\end{tabular}


Table 2. Four research proposals for social entrepreneurship emergence with a social network lens

\begin{tabular}{ll}
\hline $\begin{array}{l}\text { Theme / Theoretical } \\
\text { framework }\end{array}$ & Research proposals in social entrepreneurship \\
\hline Resource distribution & $\begin{array}{l}\text { Dense networks (i.e. enclaves) formed by solidarity among } \\
\text { marginalized individuals is a fertile ground for the emergence } \\
\text { of social entrepreneurship, in order for these individuals to get } \\
\text { alternative access to resources. }\end{array}$ \\
\hline $\begin{array}{l}\text { Diffusion of ideas and } \\
\text { network density }\end{array}$ & $\begin{array}{l}\text { Greater connectivity, among others through new technologies, } \\
\text { is a driver of social entrepreneurship emergence by increasing } \\
\text { awareness of the social needs and of social opportunities. }\end{array}$ \\
\hline $\begin{array}{l}\text { Structural holes and network } \\
\text { heterogeneity }\end{array}$ & $\begin{array}{l}\text { The bridging of different logics (market, social welfare, etc.) } \\
\text { and different networks may constitute an opportunity for new } \\
\text { solutions to social needs and hence, driving social } \\
\text { entrepreneurship. }\end{array}$ \\
\hline Network crystallisation & $\begin{array}{l}\text { The coalition of a series of actors brought together by social } \\
\text { needs may trigger social entrepreneurship through the } \\
\text { cohesion acquired from their commitment to achieving a social } \\
\text { goal. }\end{array}$ \\
\hline
\end{tabular}

